\title{
Response of milk fatty acid profile to various protein levels in goat diets with similar fatty acid content $^{*}$
}

\author{
M. Czauderna ${ }^{1}$ J. Kowalczyk, T. Żebrowska, J.P. Michalski \\ and I. Wąsowska
}

The Kielanowski Institute of Animal Physiology and Nutrition, Polish Academy of Sciences 05-110 Jabtonna, Poland

\begin{abstract}
The aim of the study was to evaluate the influence of feeding different protein levels $(11.4,13.3$ and $16.9 \%$ ) in diets for goats on the fatty acid (FA) profile in milk. The experimental design was $3 \times 3$ Latin square. Each 22-day experimental period consisted of 14 days adaptation to the diets and 8 days for milk sample collection. Separation of methylated FAs was achieved using GLC. Milk production was nearly the same when the low- and medium-protein diets were fed, while the highprotein diet resulted in a tendency to increase milk production. The concentrations of total saturated fatty acids (SFA) were similar in milk from goats fed the diets containing low- and medium-protein contents, while the diet containing the highest content of protein resulted in a slight increase in the concentration and daily production of SFA milk. The concentration and daily production of monounsaturated fatty acids, CLA isomers, other polyunsaturated fatty acids and the sum of FAs in milk increased as the dietary protein level rose. The highest dietary protein content resulted in an increase in the $\Delta 9$-desaturase index.
\end{abstract}

KEY WORDS: fatty acids, conjugated linoleic acid isomers, protein level, milk, goats

\section{INTRODUCTION}

Milk and dairy products make a significant contribution to human nutrition, including essential fatty acids (e.g., linoleic and linolenic acid), high-quality protein, and numerous vitamins and minerals. Although milk and dairy products provide essential nutrients, there is growing demand to increase the content of

\footnotetext{
${ }^{*}$ Supported in part by the State Committee for Scientific Research, Grant No. 2 P06Z 06329

${ }^{1}$ Corresponding author: e-mail: m.czauderna@ifzz.pan.pl
} 
health-promoting components in milk and dairy products. Altering the milk fatty acid (FA) profile through dietary manipulations has gained significant attention because of its implications for human health. Dietary manipulations should result in increasing polyunsaturated fatty acids (PUFA), CLA isomers and the value of the PUFAn-3/PUFAn-6 ratio (Chilliard et al., 2003). Differences between goats and cows in milk fat content and FA profile in response to dietary manipulations were recently reviewed (Chilliard and Ferlay, 2004; Chichlowski et al., 2005). To our knowledge, there are few studies on the effect of dietary manipulation on the CLA isomer profile in goats' milk. Thus, the aim of this study was to evaluate the effect of feeding different dietary protein levels on the FA profile, PUFAn-3 and CLA isomers in goats' milk.

\section{MATERIAL AND METHODS}

The study was performed on 3 dairy primiparous Alpine goats ( $\sim 12$ months old) in similar lactation phases. The experimental design was $3 \times 3$ Latin squares. Goats were housed in separate metabolic cages, fed every $6 \mathrm{~h}$ with three diets containing $11.4,13.3$ and $16.9 \%$ of crude protein in DM; water was freely available. The $22-$ day period consisted of 14 days adaptation to the diets (Table 1) and 8 days for milk collection. Goats were milked twice a day at 06.00 and 18.00 , weighed and pulled for $24 \mathrm{~h}$. Milk samples were stored at $-20^{\circ} \mathrm{C}$ until analysis. Thawed milk samples were warmed to $38^{\circ} \mathrm{C}$ and sonicated for $1 \mathrm{~min}$. Milk hydrolysis, extraction, FA methylation and separation of methylated FAs was carried out using the GLCFID method as previously described (Czauderna et al., 2007). The data were statistically analysed using the nonparametric Mann-Whitney $U$ test for comparing independent experimental groups (fatty acids concentration and the protein level in the diet). The Statistica v. 6 package was used (Statistica by StatSoft, 2002. Web: www.statsoft.pl ).

\section{RESULTS AND DISCUSSION}

The results (Table 1) demonstrated that there were substantial differences between groups in crude protein intake, while negligible differences in FA and metabolizable energy intake. Milk production was practically the same when the low- and medium-protein diets were fed, while the high protein diet resulted in a tendency $(\mathrm{P}<0.083)$ to increase milk production in comparison with goats fed the low-protein diet. As shown in Table 2, the concentration $(\mathrm{g} / \mathrm{l})$ of the sum of saturated fatty acids (SFA), atherogenic SFA (A-SFA; i.e.: C12:0, C14:0 and C16:0) and thrombogenic SFA(T-SFA; i.e.: C14:0, C16:0 and C18:0) represented a substantial 
Table 1. Diet intake, ingredients, chemical composition of diets and milk production

\begin{tabular}{|c|c|c|c|}
\hline \multirow{2}{*}{ Item } & \multicolumn{3}{|c|}{ Diet, protein level } \\
\hline & low & medium & high \\
\hline Diet intake, $\mathrm{kg} /$ day $/$ goat & 1.65 & 1.62 & 1.78 \\
\hline dry mater (DM) & 1.47 & 1.44 & 1.59 \\
\hline crude protein ${ }^{3}$ & 0.168 & 0.191 & 0.273 \\
\hline metabolizable energy ${ }^{1}, \mathrm{MJ}$ & 17.5 & 17.0 & 18.7 \\
\hline \multicolumn{4}{|l|}{ Diet ingredients } \\
\hline \multicolumn{4}{|l|}{ hay } \\
\hline $\mathrm{DM}, \mathrm{g} / \mathrm{kg}$ hay & & 915 & \\
\hline crude protein, $\mathrm{g} / \mathrm{kg} \mathrm{DM}$ & & 113 & \\
\hline crude fibre, $\mathrm{g} / \mathrm{kg} \mathrm{DM}$ & & 307 & \\
\hline metabolizable energy (ME) & & $10.6 \mathrm{M}$ & \\
\hline \multicolumn{4}{|l|}{ concentrate, $\mathrm{g} / \mathrm{kg}$} \\
\hline barley grain & 116 & 115 & 116 \\
\hline dried beet pulp & 401 & 400 & 404 \\
\hline wheat starch & 359 & 288 & 136 \\
\hline soyabean meal & 104 & 177 & 324 \\
\hline Polfamix OK & 20 & 20 & 20 \\
\hline total fatty acids & 3.20 & 3.78 & 5.49 \\
\hline $\mathrm{ME}, \mathrm{MJ} / \mathrm{kg}$ concentrate & 14.1 & 12.6 & 12.4 \\
\hline $\mathrm{DM}, \mathrm{g} / \mathrm{kg}$ & 892 & 897 & 897 \\
\hline crude protein, $\mathrm{g} / \mathrm{kg} \mathrm{DM}$ & 111 & 151 & 216 \\
\hline crude fibre, $\mathrm{g} / \mathrm{kg} \mathrm{DM}$ & 85 & 84 & 81 \\
\hline Milk production, $\mathrm{kg} /$ day $/$ goat $^{2}$ & $1.57^{\mathrm{a}}$ & $1.50^{\mathrm{a}}$ & $1.78^{\mathrm{b}}$ \\
\hline
\end{tabular}

${ }^{1}$ metabolizable energy calculated according to Energy Allowances and Feeding System for Ruminants, MAFF, London Techn. Bull., p. 33; ${ }^{2}$ values sharing different letters differed at $\mathrm{P}<0.1$

proportion of all assayed fatty acids ( $\Sigma \mathrm{FA})$ in milk and their concentrations were practically the same in milk from goats independently of the level of protein in the diet. Feeding the diet with high content protein resulted in the highest daily production $(\mathrm{g})$ of SFA, A-SFA and T-SFA in milk. Increasing the protein content in the diet resulted in an elevated concentration and daily production of C18:0 in milk. The concentration and daily production of MUFA, MUFA containing trans double bonds (MUFAt), PUFA and $\Sigma F A$ in milk increased as the level of protein rose in the diet. The highest content of protein in the diet resulted in an increase of values of PUFAn-6/PUFAn-3 ratio, while tending to decrease the concentration of PUFAn-3 in milk.

Increasing amount of protein in the diet numerically decreased the $\Delta 9$ desaturase ${ }^{\text {C14:1/C14:0 }}$ index compared with this index in milk of goats fed the diets containing medium and low levels of protein. Surprisingly, the values of the 
$\Delta 9$-desaturase index, determined from cis9C14:1 ( $c 9 \mathrm{C} 14: 1), c 9 \mathrm{C} 16: 1, c 9 \mathrm{C} 18: 1$, C14:0, C16:0 and C18:0, numerically increased as the content of protein in the diet increased. The $\Delta 9$-desaturase ${ }^{\mathrm{C} 14: 1 / \mathrm{C} 14: 0}$ index based on nearly completely de novo synthesized C14:1 is a better criterion for evaluation of the magnitude of the $\Delta 9$-desaturation compared with the $\Delta 9$-desaturase index determined from c9 $14: 1, c 9 \mathrm{C} 16: 1, c 9 \mathrm{C} 18: 1, \mathrm{C} 14: 0, \mathrm{C} 16: 0$ and $\mathrm{C} 18: 0$. The concentrations and daily production of $c 9 \mathrm{C} 18: 1, c 9 t 11 \mathrm{CLA}$ and the sum of detected CLA isomers ( $C \mathrm{CLA}$ ) in milk were higher by feeding the diet containing the high level of protein. The changes in the $c 9 t 11$ CLA concentration correlate well with the changes in the concentration of CLA isomer precursors (i.e. t11C18:1).

The concentrations and daily production of $c 9 c 12 \mathrm{C} 18: 2, c 11 c 14 \mathrm{C} 20: 2$ and c11c14c17C20:3 were increased $(\mathrm{P}<0.05)$ or numerically elevated in milk as the content of protein in the diet increased, while the decrease in the concentration and daily production of other non-CLA PUFA decreased in milk with increasing the dietary protein content. Correlations $\left(\mathrm{r}_{\mathrm{g} / 1}\right.$ and $\mathrm{r}_{\mathrm{g}}$ ) between crude protein intake (Table 1) and the concentration and daily production of FAs in milk are higher and positively associated with products of $\Delta 9-, \Delta 6-, \Delta 5-, \Delta 4$-desaturation and elongation of dietary fatty acids (Rioux et al., 2005): $c 6 c 9 c 12 \mathrm{C} 18: 3, c 11 c 14$ $\mathrm{C} 20: 2, \quad c 11 c 14 c 17 \mathrm{C} 20: 3, \quad c 5 c 8 c 11 c 14 c 17 \mathrm{C} 20: 5, \quad c 7 c 10 c 13 c 16 c 19 \mathrm{C} 22: 5$ and $c 4 c 7 c 10 c 13 c 16 c 19 \mathrm{C} 22: 6$ (i.e. $\mathrm{r}_{\mathrm{g} / 1}$ and $\mathrm{r}_{\mathrm{g}}>0.91$ ) than with other assayed FAs in milk (Table 2). The inverse correlations were associated only with the concentration of A-SFA and the value of the $\Delta 9$-desaturase $\mathrm{C}^{\mathrm{C} 14: 1 / \mathrm{C} 14: 0}$ index. The current results clearly show that the concentration and daily production of PUFA, CLA isomers and the value of the PUFA/SFA ratio depended on the level of protein in the diet. As can be seen from the obtained results, the increase in the PUFA concentration and the value of the PUFA/SFA ratio were mainly due to the increase in the concentrations of $c 9 t 11 \mathrm{CLA}, c 9 c 12 \mathrm{C} 18: 2, c 11 c 14 \mathrm{C} 20: 2$ and $c 11 c 14 c 17 \mathrm{C} 20: 3$ in milk. We suggest that the increase of the dietary protein content increased the capacity of $\Delta 9$-desaturation and elongation. We also hypothesize that increasing the protein content in the diets decreased the yield of complete biohydrogenation of PUFA in the rumen, therefore, the concentration of $t 11 \mathrm{C} 18: 1$ in milk increased. All these effects are responsible for the increase in the concentration and daily production of $c 9 t 11 \mathrm{CLA}, c 9 c 12 \mathrm{C} 18: 2, c 11 c 14 \mathrm{C} 20: 2$ and $c 11 c 14 c 17 \mathrm{C} 20: 3$. Consequently, the PUFA concentration and the PUFA/SFA ratio increased in milk. Therefore, we argue that increasing the protein concentration in the diet resulted in improving the nutritional quality of milk due to increases in the concentration of PUFA and the sum of CLA isomers, particularly c9t11CLA (Leiber et al., 2005). Unfortunately, enhancement of the protein content in the diet caused a decrease in the concentration of healthy PUFA n-3 and resulted in an increase in the value of the PUFA n-6/PUFA n-3 ratio in milk. Unexpectedly, the concentration and/or daily production of $c 6 c 9 c 12 \mathrm{C} 18: 3, c 5 c 8 c 11 c 14 \mathrm{C} 20: 4 c 5 c 8 c 11 c 14 c 17 \mathrm{C} 20: 5$ and 
Table 2. Fatty acid profile in milk of goats fed diets containing various protein concentrations

\begin{tabular}{|c|c|c|c|c|c|c|c|c|}
\hline \multirow{3}{*}{$\begin{array}{l}\text { Fatty acid content } \\
\text { in milk }{ }^{1}\end{array}$} & \multicolumn{6}{|c|}{ Diet, protein level } & \multirow{2}{*}{\multicolumn{2}{|c|}{ Correlation }} \\
\hline & \multicolumn{2}{|c|}{ low } & \multicolumn{2}{|c|}{ medium } & \multicolumn{2}{|c|}{ high } & & \\
\hline & $\mathrm{g} / 1$ & $\mathrm{~g}^{2}$ & $\mathrm{~g} / 1$ & $\mathrm{~g}^{2}$ & $\mathrm{~g} / \mathrm{l}$ & $\mathrm{g}^{2}$ & $r_{g / 1}$ & $r_{g}$ \\
\hline SFA & $6.7^{\mathrm{a}}$ & $10.5^{\alpha}$ & $6.7^{\mathrm{ab}}$ & $10.5^{\alpha \beta}$ & $6.8^{\mathrm{b}}$ & $12^{\beta}$ & 0.549 & 0.467 \\
\hline A-SFA ${ }^{3}$ & $4.1^{\mathrm{a}}$ & $6.5^{\alpha}$ & $3.9^{\mathrm{a}}$ & $6.2^{\alpha \beta}$ & $3.9^{\mathrm{a}}$ & $6.8^{\beta}$ & -0.723 & 0.634 \\
\hline T-SFA ${ }^{4}$ & $2.90^{\mathrm{a}}$ & $4.5^{\alpha}$ & $2.93^{\mathrm{a}}$ & $4.5^{\alpha}$ & $2.94^{\mathrm{a}}$ & $5.17^{\alpha}$ & 0.868 & 0.960 \\
\hline C18:0 & $0.529^{\mathrm{a}}$ & $0.83^{\alpha}$ & $0.720^{\mathrm{b}}$ & $1.12^{\beta}$ & $0.805^{\mathrm{c}}$ & $1.42^{x}$ & 0.228 & 0.158 \\
\hline$c 9 \mathrm{C} 18: 1$ & $0.858^{\mathrm{a}}$ & $1.35^{\alpha}$ & $1.05^{\mathrm{b}}$ & $1.63^{\beta}$ & $1.10^{c}$ & $1.93^{x}$ & 0.323 & 0.245 \\
\hline MUFA & $1.19^{\mathrm{a}}$ & $1.87^{\alpha}$ & $1.44^{\mathrm{b}}$ & $2.23^{\beta}$ & $1.53^{\mathrm{c}}$ & $2.68^{x}$ & 0.380 & 0.283 \\
\hline$t 11 \mathrm{C} 18: 1$ & $0.062^{\mathrm{a}}$ & $0.10^{\alpha}$ & $0.092^{\mathrm{ab}}$ & $0.14^{\alpha \beta}$ & $0.104^{b}$ & $0.18^{\beta}$ & 0.093 & 0.106 \\
\hline MUFA $t$ & $0.127^{\mathrm{a}}$ & $0.20^{\alpha}$ & $0.146^{\mathrm{a}}$ & $0.23^{\alpha}$ & $0.194^{\mathrm{b}}$ & $0.35^{\beta}$ & 0.006 & 0.020 \\
\hline PUFA & $0.497^{\mathrm{a}}$ & $0.78^{\alpha}$ & $0.540^{\mathrm{a}}$ & $0.85^{\alpha}$ & $0.566^{\mathrm{b}}$ & $1.0^{\beta}$ & 0.446 & 0.333 \\
\hline PUFAn-3 & $0.096^{\mathrm{a}}$ & $0.15^{\alpha}$ & $0.096^{\mathrm{a}}$ & $0.15^{\alpha}$ & $0.089^{\mathrm{a}}$ & $0.16^{\alpha}$ & 0.018 & 0.042 \\
\hline PUFAn-6/PUFAn-3 & \multicolumn{2}{|c|}{$4.203^{\mathrm{a}}$} & \multicolumn{2}{|c|}{$4.654^{\mathrm{ab}}$} & \multicolumn{2}{|c|}{$5.373^{\mathrm{b}}$} & \multicolumn{2}{|c|}{0.994} \\
\hline${ }^{5} \Delta 9$-index ${ }^{\text {C14:1/C14:0 }}$ & \multicolumn{2}{|c|}{$0.0249^{\mathrm{a}}$} & \multicolumn{2}{|c|}{$0.0258^{\mathrm{a}}$} & \multicolumn{2}{|c|}{$0.0240^{\mathrm{a}}$} & \multicolumn{2}{|c|}{-0.691} \\
\hline$\Delta 9$-index ${ }^{6}$ & \multicolumn{2}{|c|}{$0.1923^{\mathrm{a}}$} & \multicolumn{2}{|c|}{$0.2222^{\mathrm{a}}$} & \multicolumn{2}{|c|}{$0.2281^{\mathrm{a}}$} & \multicolumn{2}{|c|}{0.820} \\
\hline PUFA/SFA & \multicolumn{2}{|c|}{$0.0746^{\mathrm{a}}$} & \multicolumn{2}{|c|}{$0.0806^{\mathrm{a}}$} & \multicolumn{2}{|c|}{$0.0834^{\mathrm{a}}$} & \multicolumn{2}{|c|}{0.902} \\
\hline$\Sigma$ FAs & $8.3^{\mathrm{a}}$ & $13.2^{\alpha}$ & $8.7^{\mathrm{ab}}$ & $13.5^{\alpha}$ & $8.9^{\mathrm{b}}$ & $15.7^{\beta}$ & 0.560 & 0.461 \\
\hline$\Sigma$ CLA & $0.079^{\mathrm{a}}$ & $0.13^{\alpha}$ & $0.092^{\mathrm{b}}$ & $0.14^{\beta}$ & $0.118^{c}$ & $0.21^{x}$ & 0.132 & 0.145 \\
\hline c9t11CLA & $0.064^{\mathrm{a}}$ & $0.10^{\alpha}$ & $0.074^{\mathrm{b}}$ & $0.12^{\beta}$ & $0.099^{\mathrm{c}}$ & $0.18^{x}$ & 0.212 & 0.208 \\
\hline$c 9 c 12 \mathrm{C} 18: 2$ & $0.253^{\mathrm{a}}$ & $0.40^{\alpha}$ & $0.282^{\mathrm{b}}$ & $0.44^{\beta}$ & $0.290^{\mathrm{c}}$ & $0.51^{x}$ & 0.341 & 0.244 \\
\hline$c 9 c 12 c 15 \mathrm{C} 18: 3$ & $0.060^{\mathrm{a}}$ & $0.09^{\alpha}$ & $0.058^{\mathrm{a}}$ & $0.09^{\alpha}$ & $0.053^{\mathrm{a}}$ & $0.09^{\alpha}$ & 0.265 & 0.271 \\
\hline$c 6 c 9 c 12 \mathrm{C} 18: 3$ & $0.007^{\mathrm{a}}$ & $0.012^{\alpha}$ & $0.007^{\mathrm{a}}$ & $0.011^{\alpha}$ & $0.006^{\mathrm{a}}$ & $0.011^{\alpha}$ & 0.928 & 0.929 \\
\hline c11c14C20:2 & $4.5^{\mathrm{a}}$ & $0.007^{\alpha}$ & $4.7^{\mathrm{a}}$ & $0.007^{\alpha}$ & $4.9^{\mathrm{a}}$ & $0.009^{\alpha}$ & 0.958 & 0.956 \\
\hline c11c14c17C20:3 & $3.8^{\mathrm{a}}$ & $0.006^{\alpha}$ & $4.2^{\mathrm{ab}}$ & $0.007^{\alpha \beta}$ & $4.5^{\mathrm{b}}$ & $0.008^{\beta}$ & 0.978 & 0.979 \\
\hline$c 5 c 8 c 11 c 14 \mathrm{C} 20: 4$ & $34.0^{\mathrm{a}}$ & $0.054^{\alpha}$ & $34.1^{\mathrm{a}}$ & $0.054^{\alpha}$ & $30.0^{\mathrm{a}}$ & $0.054^{\alpha}$ & 0.657 & 0.664 \\
\hline$c 5 c 8 c 11 c 14 c 17 \mathrm{C} 20: 5$ & $14.7^{\mathrm{a}}$ & $0.023^{\alpha}$ & $16.2^{\mathrm{a}}$ & $0.025^{\alpha}$ & $14.4^{\mathrm{a}}$ & $0.0255^{\alpha}$ & 0.913 & 0.921 \\
\hline$c 7 c 10 c 13 c 16 c 19 \mathrm{C} 22: 5$ & $12.6^{\mathrm{a}}$ & $0.020^{\alpha}$ & $12.8^{\mathrm{a}}$ & $0.020^{\alpha}$ & $12.3^{\mathrm{a}}$ & $0.022^{\alpha}$ & 0.935 & 0.939 \\
\hline$c 4 c 7 c 10 c 13 c 16 c 19 \mathrm{C} 22: 6$ & $4.6^{\mathrm{a}}$ & $0.007^{a}$ & $4.6^{\mathrm{a}}$ & $0.007^{\alpha}$ & $4.8^{\mathrm{a}}$ & $0.008^{\alpha}$ & 0.975 & 0.975 \\
\hline
\end{tabular}

${ }^{1}$ means in rows not sharing the same letter are significantly different: $a, b$ or $\alpha, \beta \mathrm{P}<0.05 ;{ }^{2}$ the daily production (g) of all assayed fatty acids ( $\mathrm{FFAs}$ ) in milk; ${ }^{3}$ atherogenic saturated FAs (A-SFA): the sum of $\mathrm{C} 12: 0, \mathrm{C} 14: 0$ and $\mathrm{C} 16: 0 ;{ }^{4}$ thrombogenic saturated FAs (T-SFA): the sum of C14:0, C16:0 and $\mathrm{C} 18: 0 ;{ }^{5} \Delta 9$-index ${ }^{\mathrm{C} 14: 1 / \mathrm{C} 14: 0}: \Delta 9$-desaturase index $=c 9 \mathrm{C} 14: 1 /(\mathrm{C} 14: 0+c 9 \mathrm{C} 14: 1) ;{ }^{6} \Delta 9$-index $=$ $(c 9 \mathrm{C} 14: 1+c 9 \mathrm{C} 16: 1+c 9 \mathrm{C} 18: 1) /(\mathrm{C} 14: 0+c 9 \mathrm{C} 14: 1+\mathrm{C} 16: 0+c 9 \mathrm{C} 16: 1+\mathrm{C} 18: 0+c 9 \mathrm{C} 18: 1) ;{ }^{7} \mathrm{r}_{\mathrm{g} / 1}, \mathrm{r}_{\mathrm{g}}-$ the correlation coefficients between crude protein intake (Table 1) and the concentration ( $\mathrm{g} / \mathrm{l}$ ) of $\Sigma \mathrm{FAs}$ and the daily production ( $\mathrm{g}$ ) of all assayed FAs in milk, respectively

c7c10c13c16c19C22:5 were numerically lowest in the milk of goats fed the highprotein diet.

Considering the above, we suggest that the diet containing the high amount of protein decreased the capacity of $\Delta 5$-, $\Delta 6$-desaturases, therefore, the formation yield of products of $\Delta 6$-, $\Delta 5$-desaturation and elongation decreased. We hypothesize that 
the high-protein diet slightly elevated the capacity of $\Delta 4$-desaturases, consequently, the concentration and daily production of $c 4 c 7 c 10 c 13 c 16 c 19 \mathrm{C} 22: 6$ tended to be most effectively increased in the milk of goats fed this diet.

\section{CONCLUSIONS}

The increase the content of protein in the diet improves the health promoting properties of milk such as an increased content of PUFA and, in particular, the sum of CLA isomers and PUFA/SFA ratio. We hypothesized that decreasing the yield of biohydrogenation in a rumen of goats fed diets containing the higher content of protein is mainly responsible for increase of the level of $t 11 \mathrm{C} 18: 1$. In consequence, the $c 9 t 11 \mathrm{CLA}$ content in milk is positively correlated with the content of protein in the diet. In order to further increase the value of milk, in the future we intend to investigate the correlation between the content of protein in diets and contents of PUFAn-3, CLA isomers and their metabolites in milk and blood plasma, as these FAs are important due to their potential health benefits, such as anticarcinogenic properties.

\section{REFERENCES}

Chichlowski M.W., Schroeder J.W., Park C.S., Keller W.L., Schrimek D.E., 2005. Altering the fatty acids in milk by including canola seed in dairy cattle diets. J. Dairy Sci. 88, 3084-3094

Chilliard Y., Ferlay A., 2004. Dietary lipid and forage interactions on cow and goat milk fatty acid composition and sensory properties. Repord. Nutr. Develop. 44, 467-492

Chilliard Y., Ferlay A., Rouel J., Lamberet G., 2003. A review of nutritional and physiological factors affecting goat milk lipid synthesis and lypolysis. J. Dairy Sci. 86, 1751-1770

Czauderna M., Kowalczyk J., Korniluk K., Wąsowska I., 2007. Improved saponification followed by mild base- and acid-catalyzed methylations is a useful method for quantifying fatty acids, with special emphasis on conjugated dienes. Acta Chromatogr. 18 (in press)

Leiber F., Krauzer M., Nigg D., 2005. A study on the cause for the elevated n-3 fatty acids in cows' milk of Alpine origin. Lipids 40, 191-202

Rioux V., Catheline D., Bouriel M., 2005. Dietary myristic acid at physiologically relevant levels increases the tissue content of C20:5n-3 and C20:3n-6 in rats. Reprod. Nutr. Develop. 45, 599612 